\title{
The influence of the cannabinoid receptor CB1 on the periaqueductal gray in mice treated with photobiomodulation after chronic constriction injury of the sciatic nerve: a placebo-controlled trial
}

\author{
Influência do receptor canabinóide CB1 na substância cinzenta periaquedutal em camundongos \\ tratados por fotobiomodulação após constrição crônica do nervo ciático: ensaio controlado por \\ placebo
}

Gabriela Xavier Santos ${ }^{1}$, Giovane Galdino de-Souza1, Suélen Santos Alves, Gabriela Nagai Ocamoto', Nivaldo Antônio Parizotto², Luciana Maria dos-Reis ${ }^{1}$

\section{ABSTRACT}

BACKGROUND AND OBJECTIVES: Studies have demonstrated that the cannabinoid CB1 receptor is involved in the modulation of pain, mainly by activating the descending pain control pathway. However, the role of photobiomodulation in this process is not well elucidated. Thus, the present study aimed to investigate the involvement of the $\mathrm{CB} 1$ receptor in the supraspinal photobiomodulation-induced antinociception.

METHODS: Male albino swiss mice were submitted to chronic constriction injury and treated with photobiomodulation. To evaluate the supraspinal involvement of the $\mathrm{CB} 1$ receptor in the photobiomodulation-induced antinociception, the cannabinoid CB1 receptor antagonist AM251 $(0.1 \mu \mathrm{g} / \mathrm{vol} 0.2 \mu \mathrm{L})$ was injected 5 minutes before the photobiomodulation treatment. The photobiomodulation treatment was performed on the fifth day after the stereotactic surgery and chronic constriction injury at a dose of $50 \mathrm{~J} / \mathrm{cm}^{2}$ in acute condition. The hot plate and von Frey monofilaments tests were performed to evaluate the thermal and mechanical pain sensitivity, respectively.

RESULTS: The thermal and mechanical nociceptive threshold was higher in mice with chronic constriction injury, injected with saline and treated with photobiomodulation at the dose of

\footnotetext{
Gabriela Xavier Santos - Dhttps://orcid.org/0000-0002-6366-0909;

Giovane Galdino de Souza - Dhttps://orcid.org/0000-0002-1898-1973;

Suélen Santos Alves - (Dhttps://orcid.org/0000-0001-6705-233X;

Gabriela Nagai Ocamoto - (Dhttps://orcid.org/0000-0001-5496-3548;

Nivaldo Antonio Parizzoto - (Dhttp://orcid.org/0000-0003-1774-9053;

Luciana Maria dos Reis - Dhttps://orcid.org/0000-0002-0672-7804.
}

1. Universidade Federal de Alfenas, Departamento de Fisioterapia, Alfenas, MG, Brasil.

2. Universidade Federal de Sẫo Carlos, Departamento de Fisioterapia, São Carlos, SP, Brasil.

Submitted on September 18, 2018.

Accepted for publication on December 09, 2019.

Conflict of interests: none - Sponsoring sources: Fundação de Amparo à Pesquisa do Estado de Minas Gerais (FAPEMIG), protocolo 09/20160 e Coordenaçấo de Aperfeiçoamento de Pessoal de Nível Superior (CAPES).

Correspondence to:

Universidade Federal de Alfenas

Av. Jovino Fernandes Salles, 2600 - Santa Clara

37133-840 Alfenas, MG, Brasil.

E-mail: reislucianamaria@gmail.com

(C) Sociedade Brasileira para o Estudo da Dor
$50 \mathrm{~J} / \mathrm{cm}^{2}$ in both the hot plate $(\mathrm{p}<0.001)$ and von Frey $(\mathrm{p}>0.001)$ tests. These antinociceptive effects were not detected in mice with chronic constriction injury pre-treated with AM251.

CONCLUSION: The present study suggests that CB1 receptors located in Supraspinal structures, participate in the control of neuropathic pain following photobiomodulation treatment in animals undergoing chronic constriction injury.

Keywords: Cannabinoid, Lasers, Pain, Receptors, Rehabilitation.

\section{RESUMO}

JUSTIFICATIVA E OBJETIVOS: Estudos demonstraram que o receptor canabinóide CB1 está envolvido na modulação da dor, principalmente pela ativação da via descendente de controle da dor, porém o papel da fotobiomodulação nesse processo não é bem elucidado. Assim, o presente estudo teve como objetivo investigar o envolvimento do receptor CB1 na antinocicepção induzida pela fotobiomodulação a nível supraespinhal.

MÉTODOS: Camundongos machos suíço albinos foram submetidos à lesão por constrição crônica e tratados com fotobiomodulação. Para avaliar o envolvimento supraespinhal do receptor $\mathrm{CB} 1$ na antinocicepção induzida por fotobiomodulação foi injetado o antagonista do receptor canabinóide CB1, AM251 $(0,1 \mu \mathrm{g} / \mathrm{vol} 0,2 \mu \mathrm{L}) 5$ minutos antes do tratamento com fotobiomodulação. O tratamento de fotobiomodulação foi realizado no quinto dia após cirurgia estereotática e lesão por constrição crônica, na dose de $50 \mathrm{~J} / \mathrm{cm}^{2}$ em estado agudo. Os testes de placa quente e monofilamentos de von Frey foram realizados para avaliar a sensibilidade térmica e mecânica à dor, respectivamente.

RESULTADOS: O limiar térmico e mecânico nociceptivo foi maior nos camundongos com lesão por constrição crônica, injetados com soluçáo salina e tratados com fotobiomodulação na dose de $50 \mathrm{~J} / \mathrm{cm}^{2}$ nos testes de placa quente $(\mathrm{p}<0,001)$ e von Frey $(\mathrm{p}>0,001)$. Esses efeitos antinociceptivos não foram detectados em camundongos com lesão por constriçẫo crônica tratados com AM251.

CONCLUSÂO: O presente estudo sugere que os receptores CB1 localizados nas estruturas supraespinhais participam do controle da dor neuropática, após tratamento com fotobiomodulaçáo em animais submetidos à lesão por constrição crônica.

Descritores: Canabinóide, Dor, Lasers, Reabilitação, Receptores. 


\section{INTRODUCTION}

Neuropathic pain is defined as the pain arising as a direct consequence of a lesion or disease affecting the somatosensory system either at the peripheral or central level, even in the absence of nociception $^{1,2}$.

The neuropathic pain is maladaptive and does not have biological importance. It is a significant cause of permanent incapacity, mainly when it becomes chronic. Patients usually present spontaneous pain, allodynia, and hyperalgesia and do not respond well to many types of treatment. They may also present comorbidities, such as depression, anxiety, sleep disorders, and, consequently, lower quality of life $\mathrm{e}^{3-5}$.

Pain transmission in the spinal cord is modulated by supraspinal structures, such as periaqueductal gray (PAG), which makes the neuronal connection with the locus coeruleus (LC). The LC, in its turn, is connected to the rostral ventromedial medulla (RVM), which sends projections to the dorsal horn of the spinal cord through the dorsolateral spinal funiculus. This pathway results in the inhibition of the nociceptive information ${ }^{6,7}$. Moreover, the pain caused by lesions in the peripheral nervous system and modulated by the PAG are more likely related to different systems, such as the endocannabinoid system ${ }^{8,9}$.

The endocannabinoid system consists of cannabinoid receptors 1 (CB1) and 2 (CB2), their endogenous binders, and enzymes that catalyze their biosynthesis and degradation ${ }^{10}$. The $\mathrm{CB} 1$ receptors are present mainly in the central nervous system, especially in regions related to transmission and pain modulation, such as PAG, RVM, the dorsal horn of the spinal cord, and other motor and limbic structures. On the other hand, the CB2 receptors are located mainly in the peripheral nervous system, but not exclusively ${ }^{11}$. Among the most widely used therapies to treat neuropathic pain are the pharmacological approaches. However, these treatments are not efficient all the time in many patients ${ }^{12}$. Therefore, numerous studies have focused on the search for new therapeutic strategies for the treatment of neuropathic pain. Photobiomodulation (PBM) using low-level laser therapy (LLLT) has been investigated as an alternative treatment for treating this chronic condition.

PBM is a low-cost and non-invasive approach with few contraindications and side effects ${ }^{13}$. Studies have demonstrated positive effects of PBM on neuropathic pain relief in both humans ${ }^{14-16}$ and animal models $s^{17,18}$.

The peripheral attenuation of pain by PBM occurs through two distinct mechanisms: (1) the light interacts directly with neuron promoting the temporary inhibition of the axonal transport in small nerve fibers (A $\delta$ and $C)^{19}$ and (2) the light may induce anti-inflammatory effects that reduce the oxidative stress and increase the synthesis of ATP by the activation of a cascade of metabolic effects, reducing proinflammatory cytokines, such as prostaglandins and interleukins leading to decrease the activation of nociceptors ${ }^{20}$.

However, the involvement of supraspinal structures in pain control after peripheral PBM application has not been clearly elucidated in the published studies. Therefore, the objective of our study is to identify the influence of the $\mathrm{CB} 1$ receptor on the dorsolateral column of the periaqueductal gray (dIPAG) in mice treated with photobiomodulation after chronic constriction injury (CCI) of the sciatic nerve.

\section{METHODS}

The study was designed as a placebo-controlled trial. The protocols for animal studies were performed in accordance with the IASP and the Brazilian College of Animal Experimentation (COBEA).

Initially, 35 male swiss albino mice $(35-40 \mathrm{~g})$ were used in this study. However, seventeen animals were excluded based on the following criteria: the cannula did not hit the dIPAG; the mice removed its cannula, and there was no reduction in the nociceptive threshold after CCI. Therefore, eighteen animals were included and divided into 3 groups: (1) CCI+PBM $0 \mathrm{~J} / \mathrm{cm}^{2}$, (2) $\mathrm{CCI}+\mathrm{PBM} 50 \mathrm{~J} / \mathrm{cm}^{2}$, and (3) CCI+SALINE+50J/ $\mathrm{cm}^{2}$ with 6 animals in each group. They were kept under controlled conditions (on a $12 \mathrm{~h}$ light-dark cycle and temperature at $23 \pm 2^{\circ} \mathrm{C}$ ). Mice were given ad libitum access to food and water and they were transferred to the habituation room at least one hour before the experimentation.

\section{Surgical procedures}

First, the mice were anesthetized intraperitoneally (i.p.) with ketamine $(0.5 \mathrm{~mL}$, Dopalen Brasil), xylazine $(0.25 \mathrm{~mL}$, Anasedan Brasil), and saline $(3.0 \mathrm{~mL})$, to a total volume of $0.1 \mathrm{~mL} /$ $\mathrm{kg}$. Posteriorly, the mouse head and right hind leg (region close to the sciatic nerve anatomical course) were shaved and cleaned with iodine. Then, the animals were positioned in a digital stereotaxic apparatus (Stoelting Co, wood dale, United States). After a $1 \mathrm{~cm}$ long incision, we removed all soft tissue from the surface of the skull for the cranium implantation of a stainless-steel $7 \mathrm{~mm} 26 \mathrm{G}$ guide cannulas leading to the dIPAG. We also placed a dummy into the guide cannula to reduce the risk of occlusion and infection.

The stereotaxic coordinates used for cannula implantation were established as per Franklin and Paxinos: $-4.1 \mathrm{~mm}$ posterior to bregma; $-1.4 \mathrm{~mm}$ lateral to the midline, and $-2.3 \mathrm{~mm}$ ventral to skull surface ${ }^{21}$.

After the cannula implantation, we induced the neuropathic pain through $\mathrm{CCI}^{22}$. With the mouse still anesthetized in the stereotaxic apparatus and lying on its chest, an incision was made $3-4 \mathrm{~mm}$ below the femur, and the connective tissue between the gluteus superficialis and the biceps femoris muscles was cut, enabling clear visualization of the sciatic nerve. Then, we performed the constriction of the right sciatic nerve, tying four ligatures with a double knot, using a non-inflammable sterile mononylon 6.0 with stereotaxic angle at $26^{\circ}$.

Next, the animals were placed in their own cages and monitored until they recovered from anesthesia. A period of 5 days was considered for surgery recovery, and the animals were monitored daily until the end of the experiment for signs of infection.

\section{Drug preparation and injection}

The influence of the CB1 receptor on the dIPAG was analyzed through the injection of the cannabinoid CB1 receptor antag- 
onist AM251 (0.1 $\mathrm{gg}$ - TOCRIS ${ }^{\circ}$ USA) (N-(piperidin-1-yl)-5(4-iodophenyl)-1-(2,4-dichlorophenyl)-4-methyl-1H-pyrazole3 -carboxamide) diluted in saline solution $(0.9 \%)$ with $2 \%$ of Dimethyl Sulfoxide (DMSO) or saline.

The injection of AM251 in dlPAG was given 5 days after the surgical procedure. An $8 \mathrm{~mm} 33 \mathrm{G}$ injection needle (1.0mm beyond the tip of the guide cannula) was connected to a $5 \mu \mathrm{L}$ Hamilton microsyringe (Hamilton Company') via a polyethylene tube (PE-10). The needle was introduced into the cannula for the injection of $0.2 \mu \mathrm{L}$ for 45 seconds. The movement of a small bubble air in the PE-10 was observed to confirm the successful injection of the drug ${ }^{23}$.

Application of photobiomodulation with low-level laser therapy The device used for PBM was the LASER HTM COMPACT ${ }^{\circ}$ (HTM indústria de Equipamento Eletroeletrônico Ltda, Amparo, São Paulo, Brasil). The mice were subject to irradiation with infrared aluminum gallium arsenide (AsALGa) laser with $830 \mathrm{~nm}$, continuous wavelength, fluence of $50 \mathrm{~J} / \mathrm{cm}^{2}$, and output power of $30 \mathrm{~mW}$, following a standard protocol ${ }^{24}$.

The PBM was applied immediately after the injection of the drug in dIPAG. For this procedure, the animals were gently handled to avoid stress and the laser pointer was positioned perpendicular to the skin over the CCI area. We performed a single radiation with a dose of $50 \mathrm{~J} / \mathrm{cm}^{2}$ for 300 seconds using the punctual technique. The total size of the radiated area was $1 \mathrm{~cm}^{2}$.

The mice were randomly divided into 3 groups with 6 animals per group: (1) PBM radiation at the dose of $0 \mathrm{~J} / \mathrm{cm}^{2}$, laser OFF, and injection of AM251 (CCI + PBM 0J/ $\left.\mathrm{cm}^{2}+\mathrm{AM} 251\right)$; (2) $\mathrm{PBM}$ radiation at the dose of $50 \mathrm{~J} / \mathrm{cm}^{2}$, laser $\mathrm{ON}$, and injection of AM251 (CCI + PBM 50/ $\mathrm{cm}^{2}+$ AM251). The control group, (3) $\mathrm{PBM}$ radiation at dose of $50 \mathrm{~J} / \mathrm{cm}^{2}$ with laser $\mathrm{ON}$, and injection of saline (CCI + PBM 50J/ $\mathrm{cm}^{2}+$ SALINE).

After the PBM radiation, the animals were allocated in the von Frey apparatus for acclimatization. After 30 minutes of acclimatization, the hot plate test and von Frey testing were initiated.

\section{Nociceptive tests}

The hot plate test ${ }^{24}$ was used for the evaluation of thermal hyperalgesia. The animals were placed on a $48^{\circ} \mathrm{C}\left(47.8-49.4^{\circ} \mathrm{C}\right)$ hot plate (Insight, Brasil). The latency, time necessary, for the response to the pain stimulus (hind-paw lick, jump etc.) was recorded. In the absence of a reaction, the mice were removed from the hot plate at 30 seconds to avoid tissue injury, and 30 seconds latency was recorded as the response.
The von Frey ${ }^{5}$ monofilaments were used for the evaluation of mechanical hyperalgesia. Mice were placed in a plastic cage suspended above a wire mesh grid and allowed to move freely and acclimatize to the testing apparatus for 30 minutes before the experiments. The von Frey monofilaments (Aesthesia', EUA) were pressed against the plantar surface of the right paw. A positive response was noted if the paw was sharply withdrawn upon the application of the monofilament. We performed three measures of the nociceptive threshold for each animal, separated by 3-minute intervals. The mean of the three measurements was recorded as the mechanical paw withdrawal threshold.

The hot plate test and von Frey testing were performed at three time points: (1) before the surgical procedure (baseline), (2) on the fifth day, prior to the drug infusion and PBM radiation, and (3) also on the fifth day, 30 minutes after the drug injection and PBM radiation (Figure 1). Animals that did not demonstrate a significant reduction in the sensory threshold (compared with the values obtained at baseline) were excluded.

\section{Histological verification of cannula placements}

After the completion of all the procedures, the cannula placement was histologically examined. To this end, the mice were anesthetized intraperitoneally with ketamine $(0.5 \mathrm{~mL})$, xylazine $(0.25 \mathrm{~mL})$, and saline $(3.0 \mathrm{~mL})$, to a total volume of $0.1 \mathrm{~mL} / \mathrm{kg}$. Next, the mice received injections of polyethylene blue, following the same protocol described previously. Then, the mice were euthanized, and their brains were removed and immersed in $10 \%$ formalin for fixation. The brains were frozen, and sections were cut at $40 \mu \mathrm{m}$ on a freezing microtome (Lupetec ${ }^{\circ}$, Brasil). The samples were analyzed through a microscope (Biolab, Brasil). The visualization of the methylene blue dispersion indicated the cannula placement. The animals whose cannula did not reach the dIPAG were excluded.

This study was also submitted and approved by the Ethical Committee for the Use of Animals of the Federal University of Alfenas (CEUA- UNIFAL- MG/Brasil - protocol number 09/2016).

\section{Statistical analysis}

The data are presented as mean \pm S.E.M. the statistical analysis of behavioral experiments, we performed the two-way variance analysis (ANOVA) followed by the Bonferroni post hoc test for multiple comparisons, being considered statistically significant values of $\mathrm{p}<0.01$. Statistical analysis and preparation of figures were performed using GraphPad Prism Software, Version 5 (GraphPad Software, La Jolla, CA).

\begin{tabular}{|c|c|c|c|c|c|}
\hline Day 1 & Day 2 & \multicolumn{4}{|c|}{ Day 5} \\
\hline 1 & $\mid$ & 1 & | & 1 & | \\
\hline Basal measure & Surgery & Before PBM: & Infusion: & PBM & 30' after PBM: \\
\hline Von Frey & Stereotaxic & Von Frey & AM251 or & - & Von Frey \\
\hline Hot plate & $\mathrm{CCl}$ & Hot plate & saline & - & hot plate \\
\hline
\end{tabular}

Figure 1. Timeline representation of the experimental protocol

$\mathrm{CCl}=$ chronic constriction injury; PBM = photobiomodulation using low-level laser therapy; AM251 = (N-(piperidin-1-yl)-5-(4-iodophenyl)-1-(2,4-dichlorophenyl)-4methyl-1H-pyrazole-3-carboxamide)- Cannabinoid CB1 receptor antagonist. 


\section{RESULTS}

Figure 2 shows the results concerning the thermal nociceptive threshold assessed by the hot plate test. We observed that after the $\mathrm{CCI}$ there was a reduction of the nociceptive thermal threshold in all the evaluated groups $(\mathrm{p}<0.001)$ compared to baseline. After irradiation with $\mathrm{PBM}$, a significant increase of the nociceptive thermal threshold in the (3) CCI + PBM 50J/ $\mathrm{cm}^{2}+$ saline group $(23.5 \pm 1.87)$ was observed when compared to the (1) CCI + PBM $0 \mathrm{~J} / \mathrm{cm}^{2}+$ AM251 group $(14.08 \pm 1.07)(\mathrm{p}<0.001)$, showing antinociceptive effect of $50 \mathrm{~J} / \mathrm{cm}^{2} \mathrm{PBM}$ and there was no effect of AM251 on the nociceptive threshold. The AM251 reversed the analgesic effect of the PBM as observed in the comparison between the groups (3) CCI + PBM 50J/ $/ \mathrm{cm}^{2}+$ saline $(23.5 \pm 1.87)$ and (2) CCI + PBM 50J $/ \mathrm{cm}^{2}+$ AM251 $(12.76 \pm 0.87)(\mathrm{p}<0.001)$.

Figure 3 shows the results concerning the mechanical nociceptive threshold assessed by the von Frey test. We observed that after the CCI there was a reduction of the mechanical nociceptive threshold in all the evaluated groups $(\mathrm{p}<0.001)$ compared to baseline. After irradiation with PBM, a significant increase of the nociceptive thermal threshold in the (1) CCI + PBM 50J/ $\mathrm{cm}^{2}+$ saline group $(1.065 \pm 0.071)$ was observed when compared to the (2) CCI + PBM 0J/ $/ \mathrm{cm}^{2}+$ AM251 group $(0.49 \pm 0.06)(\mathrm{p}<0.001)$, showing antinociceptive effect of $50 \mathrm{~J} / \mathrm{cm}^{2} \mathrm{PBM}$ and no effect of AM251 on the nociceptive threshold. The AM251 reversed the analgesic effect of $\mathrm{PBM}$ as observed in the comparison between the groups (1) CCI + PBM 50J/ $\mathrm{cm}^{2}+$ saline $(1.065 \pm 0.071)$ and (2) $\mathrm{CCI}+\mathrm{PBM} 50 \mathrm{~J} / \mathrm{cm}^{2}+\mathrm{AM} 251(0.50 \pm 0.07)(\mathrm{p}<0.001)$.

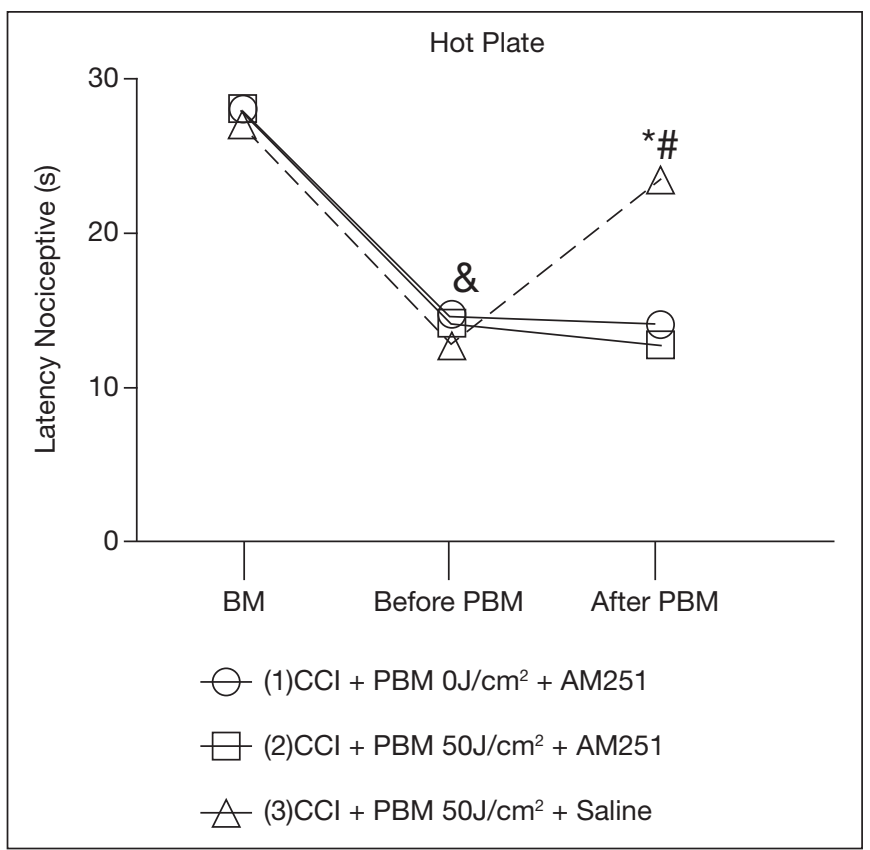

Figure 2. Effect of PBM $50 \mathrm{~J} / \mathrm{cm}^{2}$ or $0 \mathrm{~J} / \mathrm{cm}^{2}$ with intra-lateral periaqueductal gray side injection (I.dIPAG) of CB1 receptor antagonist AM251 or saline on thermal nociceptive latency of paw withdrawal, by the test of the hot plate.

$\mathrm{CCl}=$ chronic constriction injury; Moments of measurement: $\mathrm{BM}=$ baseline measurement of nociceptive threshold; Before PBM = threshold measurement before application of PBM, After PBM = measurement of threshold after PBM application. The data represent the mean $\pm S D$ of the mean; values of $p<0.01$ were considered significant.

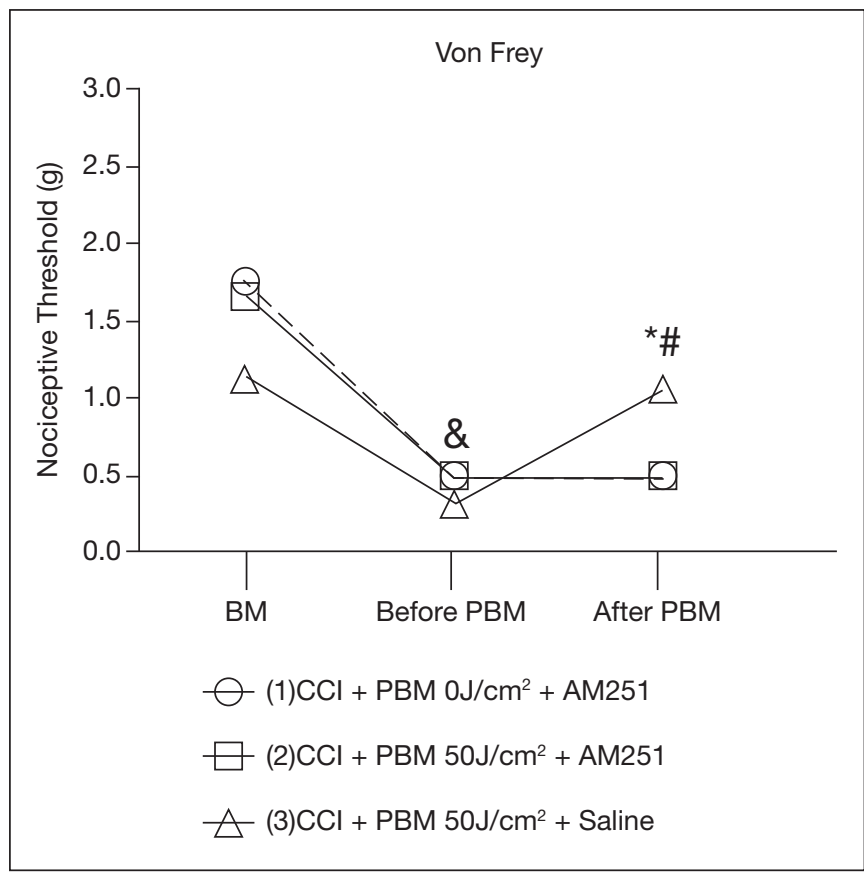

Figure 3. Effect of the PBM $50 \mathrm{~J} / \mathrm{cm}^{2}$ or $0 \mathrm{~J} / \mathrm{cm}^{2}$ associated with intra-lateral periaqueductal gray matter infusion (I.dIPAG) of CB1 receptor antagonist AM251 or saline on the mechanical nociceptive threshold of paw withdrawal, by the test of filaments of Von Frey.

$\mathrm{CCl}=$ chronic constriction injury; Moments of measurement: $\mathrm{MB}=$ baseline measurement of the nociceptive threshold; Before PBM = threshold measurement before application of PBM; After PBM = measurement of threshold af ter PBM application. The data represent the mean \pm SD of the mean; values of $\mathrm{p}<0.01$ were considered significant.

\section{DISCUSSION}

In the present study, all groups showed a reduction in the nociceptive threshold, when compared to the baseline, evaluated by the hot plate test and the von Frey test, aligning with the previous studies $^{22,24,25}$. An increase in nociceptive threshold was observed in the group (2) CCI+PBM $50 \mathrm{~J} / \mathrm{cm}^{2}+$ saline when compared with baseline values after application of $50 \mathrm{~J} / \mathrm{cm}^{2} \mathrm{PBM}$, showing good results for the treatment of neuropathic pain. Most of the previous studies showed beneficial effects even with a large variation in creep, from $1 \mathrm{~J} / \mathrm{cm}^{2}$ to $1312 \mathrm{~J} / \mathrm{cm}^{214}$. A recent study ${ }^{24}$ used the PBM with wavelength $808 \mathrm{~nm}$ and varied fluences of 10,20 , and $40 \mathrm{~J} / \mathrm{cm}^{2}$ in order to establish a therapeutic window. The results showed that only higher fluences 20 and $40 \mathrm{~J} / \mathrm{cm}^{2}$ were able to produce $\beta$-endorphin increase and effectively reduce neuropathic pain, corroborating with the results of the present study. The local peripheral effect of PBM is widely described in the literature. Hsieh et al. ${ }^{25}$ demonstrated that PBM applied transcutaneous at the CCI site reduces the levels of proinflammatory cytokines such as tumor necrosis factor- $\alpha$ (TNF- $\alpha$ ) and interleukin-1 $\beta$ (IL-1 $\beta$ ), and hypoxia-inducible factor $1 \alpha$ (HIF-1 $\alpha)$ leading to improved hypoxia/tissue ischemia. It elevates the levels of endothelial growth factor (VEGF) and nerve growth factor (NGF), resulting in improvement of functional recovery, nerve regeneration and analgesia. Another study observed the reduction of the proinflammatory cytokines Fractalkine (FKN) and IL-1 $\beta$, and the reduction of the glial satellite cells in the dorsal root ganglion, 
causing pain relief and reduced paw protection behavior behavior in animals with neuropathy and treated with $\mathrm{PBM}^{26}$.

Moreover, previous studies reinforce that the PBM provides improvement in the sciatic functional index in animals with neuropathy ${ }^{27,28}$, accelerates nerve regeneration ${ }^{29-31}$, increases the expression of the neuronal growth marker GAP 43 related to the process of regeneration ${ }^{32}$, increased number of myelinated fibers, improved electrophysiological function, and increased vascular network and collagen ${ }^{33}$.

In the present study, it was possible to observe the participation of the CB1 receptor of PAG in the antinociceptive effect after PBM, since the antagonization of these receptors by AM251, a selective antagonist of $\mathrm{CB} 1$ receptors, in the PAG, was able to reverse the antinociceptive effect of PBM $50 \mathrm{~J} / \mathrm{cm}^{2}$.

Although CNS structures play a crucial role in the modulation of neuropathic pain, there is a scarcity in the literature of data proving the involvement of supraspinal structures, especially regarding PAG, in the antinociceptive effect mediated by PBM. Similarly, the endocannabinoid system, especially the CB1 receptor, has been related to the modulation of neuropathic pain ${ }^{8,9}$. However, little is known about the participation of these receptors in supraspinal structures, such as PAG, in the modulation of neuropathic pain disorders by PBM.

A study ${ }^{34}$ showed that the intracerebroventricular and systemic administration of selective agonist of CB1 receptors, ACEA ([N-(2-chloroethyl) 5, 8, 11, 14-eicosaetraenamide]), promotes the reduction of acute and chronic mechanical allodynia in mice submitted to brachial plexus avulsion. However, this antinociceptive effect was better observed in the activation of the central pathway.

Another study reinforces the involvement of the supraspinal structures in pain control by the endocannabinoid system when performing drug infusion CP-55.940 and WIN55,212-2 (cannabinoid receptor agonist) in the lateral ventricle, an increase in the latency in the tail-withdrawal test ${ }^{35}$. In a model of neuropathic pain induced by chemotherapy, the antinociceptive effect was observed, in face of the mechanical and thermal allodynia stimulus, by inhibiting endocannabinoid resorption and its Degradation (FAHH), however, after antagonizing the receptors of $\mathrm{CB} 1$ or $\mathrm{CB} 2$, the effect provided by the inhibition of $\mathrm{FAHH}^{8}$ was completely blocked. Concerning the dlPAG, a study demonstrated that it is related to the analgesic effect induced by stress, assessed by the tail test and that this effect is mediated by the activation of the $\mathrm{CB} 1$ receptors, through its endogenous ligand anandamide and 2- Araquidonylglycerol (2-AG) ${ }^{36}$ reinforcing the results found in this study.

It is possible to suggest the participation of the $\mathrm{CB} 1$ receptor in supraspinal structures, specifically of the dIPAG, in the effect of pain modulation after treatment with PBM in mice submitted to $\mathrm{CCI}$, which makes the study pertinent since in the literature is not well Elucidated if the application of the PBM peripherical involves the participation of the CNS.

Studies aimed at understanding the mechanisms of action of resources used in clinical practice are relevant as they strengthen evidence-based practice. New studies with agonist drugs and inhibitors of endogenous endocannabinoid degradation are necessary to better elucidate the analgesia processes by the PBM.

\section{CONCLUSION}

According to the data presented, it is suggested the participation of the CB1 receptors in the dIPAG, in the antinociceptive effect promoted by the PBM by laser of gallium arsenide aluminum (AsAlGa) wavelength of 830 nanometers, continuous and with radiant power maximum and average of $30 \mathrm{~mW}$ in the intensity of $50 \mathrm{~J} / \mathrm{cm}^{2}$, after chronic constriction of the sciatic nerve.

\section{REFERENCES}

1. Haanpää M, Attal N, Backonja M, Baron R, Bennett M, Bouhassira D, Cruccu G, et al. NeuPSIG guidelines on neuropathic pain assessment. Pain. 2011;152(1):14-27.

2. Dickenson A, Suzuki, R. Targets in pain and analgesia. In: Hunt SP, Koltzenburg M. The neurobiology of pain. New York: Oxford University Press; 2005. 149-60p.

3. Nishikawa N, Nomoto M. Management of neuropathic pain. J Gen Fam Med. 2017;18(2):56-60

4. Inoue S, Taguchi T, Yamashita T, Nakamura M, Ushida T. The prevalence and impact of chronic neuropathic pain on daily and social life: a nationwide study in a Japanese population. Eur J Pain. 2017;21(4):727-37

5. Benbouzid M, Pallage V, Rajalu M, Waltisperger E, Doridot S, Poisbeau P, et al. Sciatic nerve cuffing in mice: a model of sustained neuropathic pain. Eur J Pain. 2008;12(5):591-9.

6. Suzuki R, Rahaman W, Hunt SP, Dickenson AH. Descending facilitatory control of mechanically evoked responses is enhanced in deep dorsal horn neurons following peripheral nerve injury. Brain Res. 2004;1019(1-2):68-76.

7. Vanegas H, Schaible HG. Descending control of persistent pain: inhibitory or facilitatory? Brain Res Rev. 2004;46(3):295-309.

8. Guindon J, Lai Y, Takacs SM, Bradshaw HB, Hohmann AG. Alterations in endocannabinoid tone following chemotherapy-induced peripheral neuropathy: effects of endocannabinoid deactivation inhibitors targeting fatty-acid amide hydrolase and monoacylglycerol lipase in comparison to reference analgesics following cisplatin treatment. Pharmacol Res. 2013;67(1):94-109.

9. Maldonado R, Bańos JE, Cabañero D. The endocannabinoid system and neuropathic pain. Pain. 2016;157(Suppl 1):S23-32.

10. Guindon J, Hohmann AG. The endocannabinoid system and pain. CNS Neurol Disord Drug Targets. 2009;8(6):403-21.

11. Ulugöl A. The endocannabinoid system as a potential therapeutic target for pain modulation. Balkan Med J. 2014;31(2):115-20.

12. Cruccu G, Aziz TZ, Garcia-Larrea L, Hansson P, Jensen TS, Lefaucheur JP, et al. EFNS guidelines on neurostimulation therapy for neuropathic pain. Eur J Neurol. 2007;14(9):952-70.

13. de Andrade AL, Bossini PS, Parizotto NA. Use of low level laser therapy to contro neuropathic pain: a systematic review. J Photochem Photobiol B. 2016;164:38-42.

14. Ali-Asgarzadeh A, Agha-Mohammadi D, Movasaghi R, Shahsavari P. Effect of low-intensity laser on lower limb neuropathic pain in patients with diabetes mellitus. JAP. 2011;2(2):48-60.

15. Khamseh ME, Kazemikho N, Aghili R, Forough B, Lajevardi M, Hashem Dabaghian F, et al. Diabetic distal symmetric polyneuropathy: effect of low-intensity laser therapy. Lasers Med Sci. 2011;26(6):831-5.

16. Ribas ES, Paiva WS, Pinto NC, Yeng LT, Okada M, Fonoff ET, et al. Use of low intensity laser treatment in neuropathic pain refractory to clinical treatment in amputation stumps. Int J Gen Med. 2012;5:739-42.

17. Gustafsson H, Flood K, Berge OG, Brodin E, Olgart L, Stiller CO. Gabapentin reverses mechanical allodynia induced by sciatic nerve ischemia and formalin induced nociception in mice. Exp Neurol. 2003;182(2):427-34.

18. Bertolini GR, Artifon EL, Silva TS, Cunha DM, Vigo PR. Low-level laser therapy, at $830 \mathrm{~nm}$, for pain reduction in experimental model of rats with sciatica. Arq Neuropsiquiatr. 2011;69(2-B):356-9.

19. Chow RT, David MA, Armati PJ. $830 \mathrm{~nm}$ laser irradiation induces varicosity formation, reduces mitochondrial membrane potential and blocks fast axonal flow in small and medium diameter rat dorsal root ganglion neurons: implications for the analgesic effects of $830 \mathrm{~nm}$ laser. J Peripher Nerv Syst. 2007;12(1):28-39.

20. Alves AC, Vieira R, Leal-Junior E, dos Santos S, Ligeiro AP, Albertini R, et al. Effect of low-level laser therapy on the expression of inflammatory mediators and on neutrophils and macrophages in acute joint inflammation. Arthritis Res Ther. 2013;15(5):R116.

21. Franklin KB, Paxinos G. The mouse brain in stereotaxic coordinates. New York: Academic Press; 2008.

22. Bennett GJ, Xie YK. A peripheral mononeuropathiy in rat that produces disorders of pain sensation like those seen in man. Pain. 1988;33(1):87-107.

23. Nunes-de-Souza RL, Canto-de-Souza A, da-Costa M, Fornari RV, Graeff FG, Pelá IR. Anxiety-induced antinociception in mice: effects of systemic and intra-amygdala administration of 8-OH-DPAT and midazolam. Psychopharmacology. 2000;150(3):300-10. 
24. de Andrade ALM, Bossini PS, do Canto De Souza ALM, Sanchez AD, Parizotto NA. Effect of photobiomodulation therapy $(808 \mathrm{~nm})$ in the control of neuropathic pain in mice. Lasers Med Sci. 2017;32(4):865-72.

25. Hsieh YL, Chou LW, Chang PL, Yang CC, Kao MJ, Hong CZ. Low-level laser therapy alleviates neuropathic pain and promotes function recovery in rats with chronic constriction injury: possible involvements in hypoxia-inducible factor $1 \alpha(\mathrm{HIF}-1 \alpha)$. J Comp Neurol. 2012;520(13):2903-16.

26. Oliveira ME, Santos FM, Bonifácio RP, Freitas MF, Martins DO, Chacur M. Low level laser therapy alters satellite glial cell expression and reverses nociceptive behavior in rats with neuropathic pain. Photochem Photobiol Sci. 2017;16(4):547-54.

27. Belchior AC, dos Reis FA, Nicolau RA, Silva IS, Perreira DM, de Carvalho Pde T. Influence of laser $(660 \mathrm{~nm})$ on functional recovery of the sciatic nerve in rats following crushing lesion. Lasers Med Sci. 2009;24(6):893-9.

28. Barbosa RI, Marcolino AM, de Jesus Guirro RR, Mazzer, Barbieri CH, de Cássia Registro Fonseca M. Comparative effects of wavelengths of low-power laser in regeneration of sciatic nerve in rats following crushing lesion. Lasers Med Sci. 2010;25(3):423-30.

29. dos Reis FA, Belchior AC, de Carvalho Pde T, da Silva BA, Pereira DM, Silva IS, et al. Effect of laser therapy $(660 \mathrm{~nm})$ on recovery of the sciatic nerve in rats after injury through neurotmesis followed by epineural anastomosis. Lasers Med Sci. 2009;24(5):741-7.

30. Ziago EK, Fazan VP, Iyomasa MM, Sousa LG, Yamauchi PY, da Silva EA, et al.
Analysis of the variation in low-level laser energy density on the crushed sciatic nerves of rats: A morphological, quantitative, and morphometric study. Lasers Med. Sci. 2017;32(2):369-78

31. Shen CC, Yang YC, Liu BS. Large-area irradiated low-level laser effect in a biodegradable nerve guide conduit on neural regeneration of peripheral nerve injury in rats. Injury. 2011;42(8):803-13.

32. Wang CZ, Chen YJ, Wang YH, Yeh ML, Huang MH, Ho ML, et al. Low-level laser irradiation improves functional recovery and nerve regeneration in sciatic nerve crush rat injury model. PLoS One. 2014;9(8):e103348.

33. Rosso MPO, Buchaim DV, Kawano N, Furlanette G, Pomini KT, Buchaim RL. Photobiomodulation therapy (PBMT) in peripheral nerve regeneration: a systematic review. Bioengineering. 2018;5(2). pii: E44.

34. Paszcuk AF, Dutra RC, da Silva KA, Quintão NL, Campos MM, Calixto JB. Cannabinoid agonists inhibit neuropathic pain induced by brachial plexus avulsion in mice by affecting glial cells and MAP kinases. PLoS One. 2011;6(9):e24034.

35. Martin WJ, Lai NK, Patrick SL, Tsou K, Walker JM. Antinociceptive actions of cannabinoids following intraventricular administration in rats. Brain Res. 1993;629(2):300-4.

36. Mascarenhas DC, Gomes KS, Sorregotti T, Nunes-de-Souza RL. Blockade of cannabinoid CB1 receptors in the dorsal periaqueductal gray unmasks the antinociceptive effect of local injections of anandamide in mice. Front Pharmacol. 2017;8:695. 